\title{
Biostratigraphy of Upper Valanginian - Upper Aptian Balambo Formation Near Barsarin Village in Rawanduz Area, Northeastern Iraq
}

\author{
Majid M. Al-Mutwali \\ Department of Geology \\ College of science \\ University of Mosul
}

\author{
Nabil Y. Al-Banna \\ Oil and Mining \\ Engineering College \\ University of Mosul
}

Mohammed W. Al-Abbasi

Dams and Water Resources

Research Center

University of Mosul

(Received 22/4/2014 , Accepted 5/11/2018)

\begin{abstract}
The biostratigraphy of Balambo Formation has been investigated within a well-exposed section at the northeastern limb of Zozik anticline, near Barsarin Village, northeastern Iraq. The studied section consists mainly of marl, marly limestone and limestone. These rocks yielded moderately diversified planktonic foraminiferal fauna and radiolarian skeletons, in addition to some benthonic foraminifera and bioclast. The study is focusing on planktonic foraminiferal taxa, which are classified to ten species belonging to three genera. the stratigraphic distribution of the recorded species permits the recognition of five well defined biozones. These are in descending order:

- Globigerinelloides algeriana Taxon range Zone. (part)

- Globigerinelloides ferreolensis Interval Zone.

- Globigerinelloides blowi Interval Zone.

- Hedbergella sigali Interval Zone.

- Globuligerina hoterivica Interval Zone.

The planktonic foraminiferal biozones are correlated with other zonal schemes. They are considered to be extending from Late Valanginian to Late Aptian age.
\end{abstract}

Keywords: Balambo Fn., Planktonic Foraminifera, Barsarin Iraq.

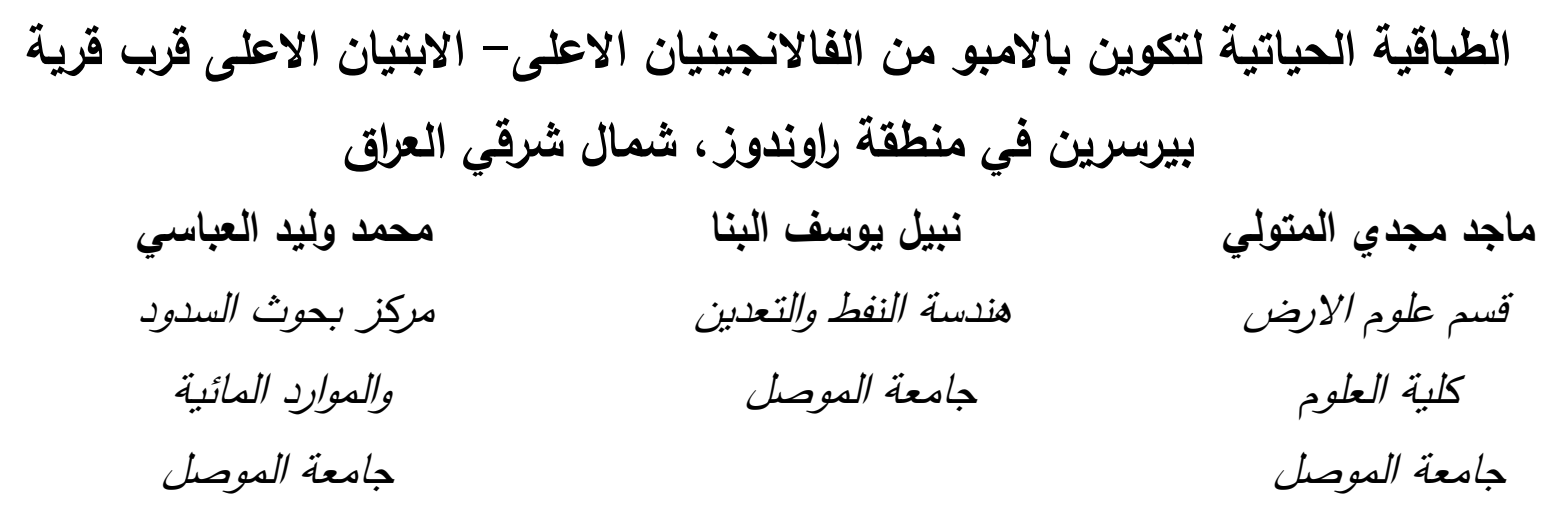




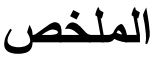

تمت دراسة الطباقية الحياتية لتكوين بالامبو ضمن مكثف صخري يقع على الغاطس الثمالي الثرقي

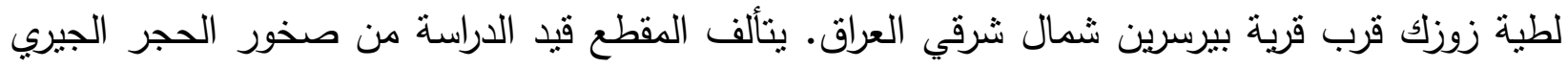

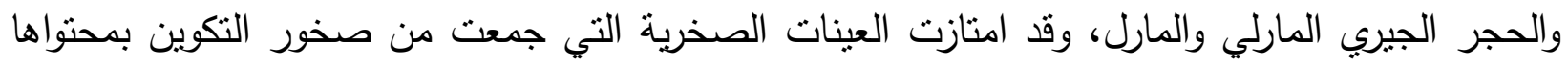

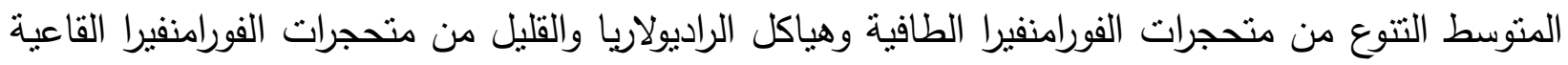

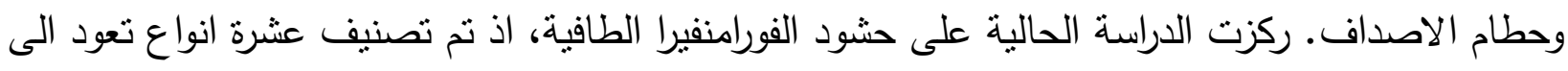

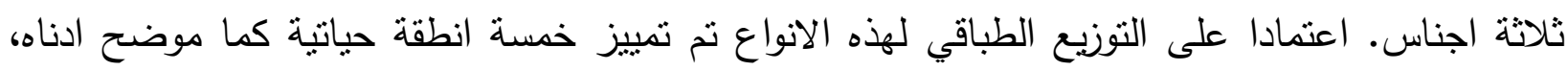

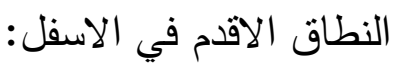

- Globigerinelloides algeriana Taxon range Zone. (part)

. Globigerinelloides ferreolensis Interval Zone.

- Globigerinelloides blowi Interval Zone.

. Hedbergella sigali Interval Zone.

- Globuligerina hoterivica Interval Zone.

تمت مضاهاة الانطقة الحياتية للاراسة الحالية مع بعض الدراسات الاخرى، واستتنج بانها تمتد من

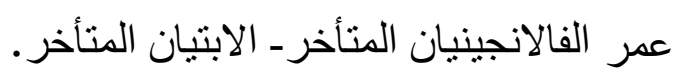

الكلمات المفتاحية: تكوين بالامبو، الفورامنفيرا الطافية، بيرسرين، العراق.

\section{INTRODUCTION}

The studied section is located in northeastern limb of Zozik anticline, near Barsarin village (Fig. 1), near Rawanduz town. The midpoint of the section is at ( $36^{\circ} 32^{\prime} 00^{\prime \prime}$ ) Latitude and ( $44^{\circ} 40^{\prime} 00^{\prime \prime}$ ) Longitude within the imbricated zone of the unstable shelf according to Jassim and Buday (2006).

The Balambo Formation (Valanginian - Turonian) was first described by Wetzel in 1947 in (Bellen et al., 1959) from Sirwan Valley, near Halabja, northeastern Iraq. The type section is about $762 \mathrm{~m}$ thick and embraces two divisions: Upper division composed of $503 \mathrm{~m}$ of thin- bedded globigerinal limestone, passing downwards to radiolarian limestone. Lower division of $259 \mathrm{~m}$ thin- bedded, blue ammonitiferous limestone with intercalation of olive green marls and dark blue shale.

The studied section is $180 \mathrm{~m}$ thick and consists of alternation of thin bedded pale brownish limestone, marly limestone and pale bluish marl. The lower boundary is recognized by the sharp contact between thick dolostone bed and thinly bedded limestone and marl of Sarmord and Balambo formations respectively. The upper boundary is gradational with the Qamchuqa Formation, 
determinate,may be determined by the alternation beds of thinly bedded marly limestone (Balambo Formation) and massive rocks of Qamchuqa Formation.

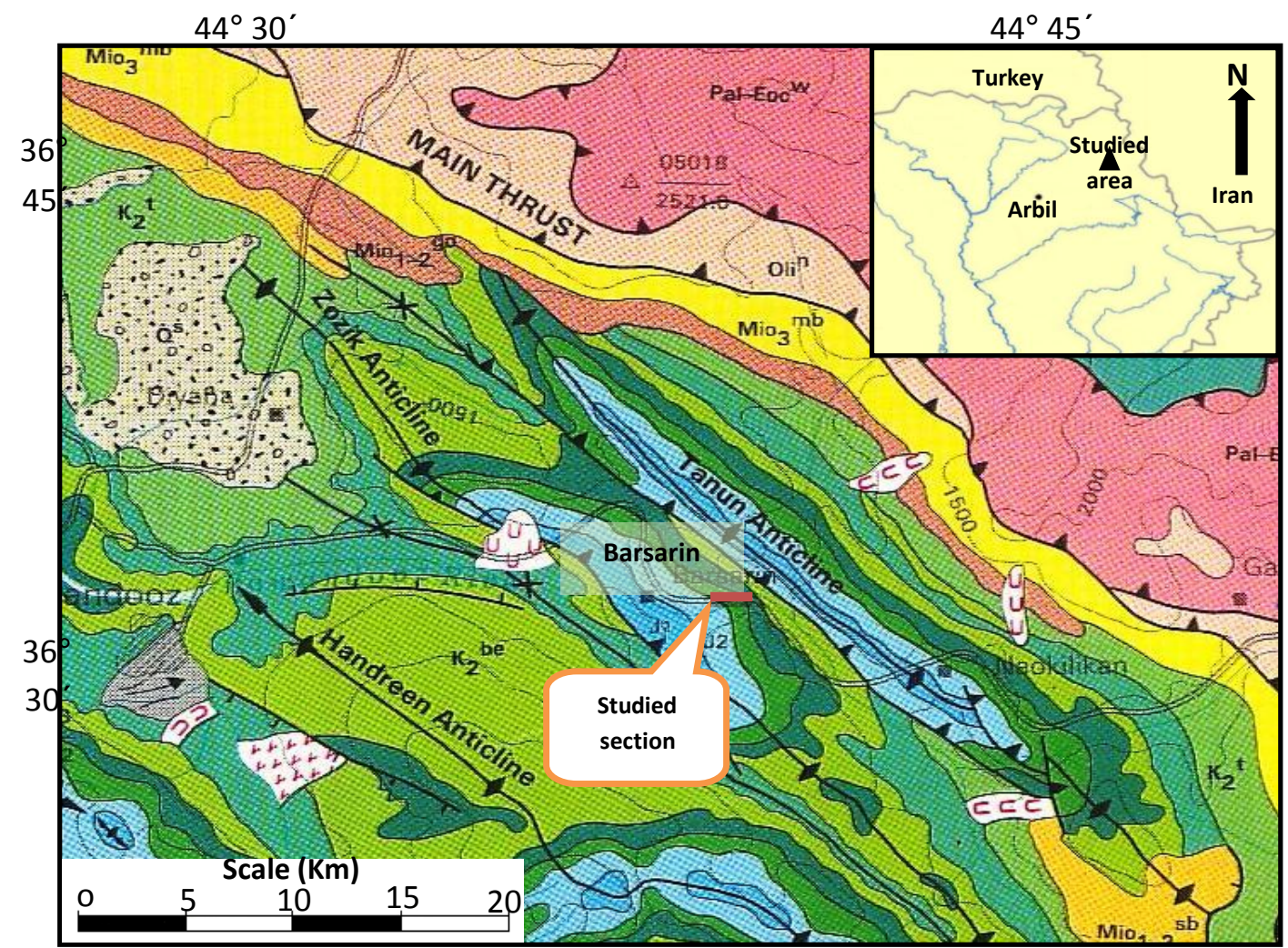

\section{Cretaceous}

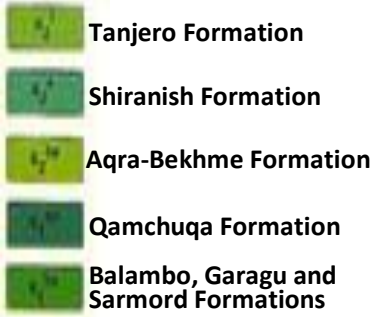

\section{LEGEND}

Jurassic

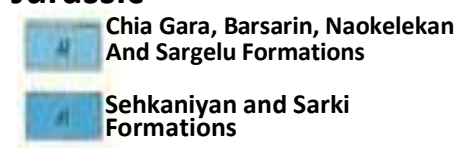

Triassic

Iy ${ }^{4}$ Baluti and Kurra Chine

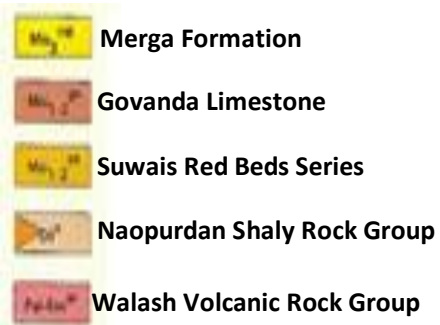

Fig. 1: Geological Map of the Sstudied Area (after Sissakian et al., 1997).

The goal of the present research is to identify the planktonic foraminiferal speciesand establishing their biostratigraphic zones, which provided the basis for age determined of the studied section. Other microfossils such as radiolaria and benthonic foraminifera are recognized, and tabulated for general biostratigraphic distribution. 


\section{BIOSTRATIGRAPHY}

The investigation of foraminiferal assemblages within the studied section revealed that planktonic foraminifera have been used for biostratigraphic analysis. This study enabled us to identify ten planktonic foraminiferal species (Fig. 2). Based on the geological time scale, which recorded by Ogg et al. (2016), the absolute age of the planktonic foraminiferal zones have been determined.

The identified planktonic foraminiferal biozones are correlated with their equivalent standard biozones in other regions of the world (Fig. 3). The studied section can be subdivided into five biozones, these biozones are described below in ascending order.

\section{1- Globuligerina hoterivica Interval Zone.}

Definition: The present zone is defined by van Hinte (1972) from the Late Hauterivian. It represents the stratigraphic range of the index species Globuligerina hoterivica (Subbotina), which precedes the appearance of Hedbergella sigali Moullade

Age: Late Valanginian.

Boundaries: The lower boundary of this zone is marked by the first appearance of index species Globuligerina hoterivica (Subbotina), whereas its upper boundary is placed at the first appearance of the species Hedbergella sigali Moullade.

Thickness: $26 \mathrm{~m}$ represented by samples $(1-9)$.

Correlation and Age Determination: The present zone is equivalent to the Globuligerina hoterivica zone of Caron (1985), Sliter (1989), Altiner (1991) and Rojay and Altiner (1998) of Late Hauterivian age in Turkey. While it is correlative to the Favusella hoterivica zone of Hardenbol et al. (1998) of Late Berriasian Late Valanginian age. Furthermore, it is equivalent to the Globuligerina hoterivica zone of Ogg et al. (2016) of Late Valanginian age. 


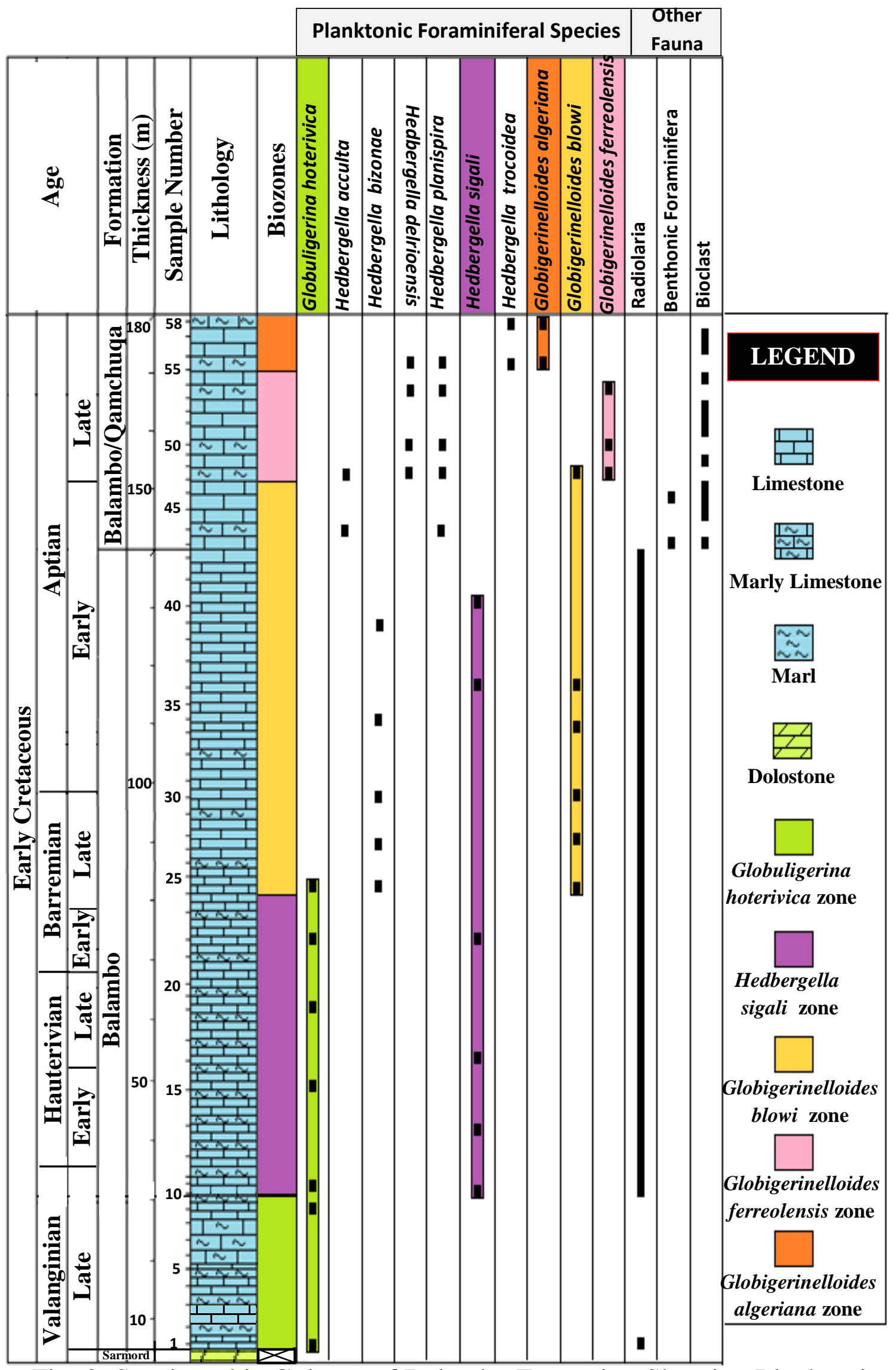

Fig. 2: Stratigraphic Column of Balambo Formation Showing Planktonic Foraminifera Ranges and its Biostratigraphic Zonation 


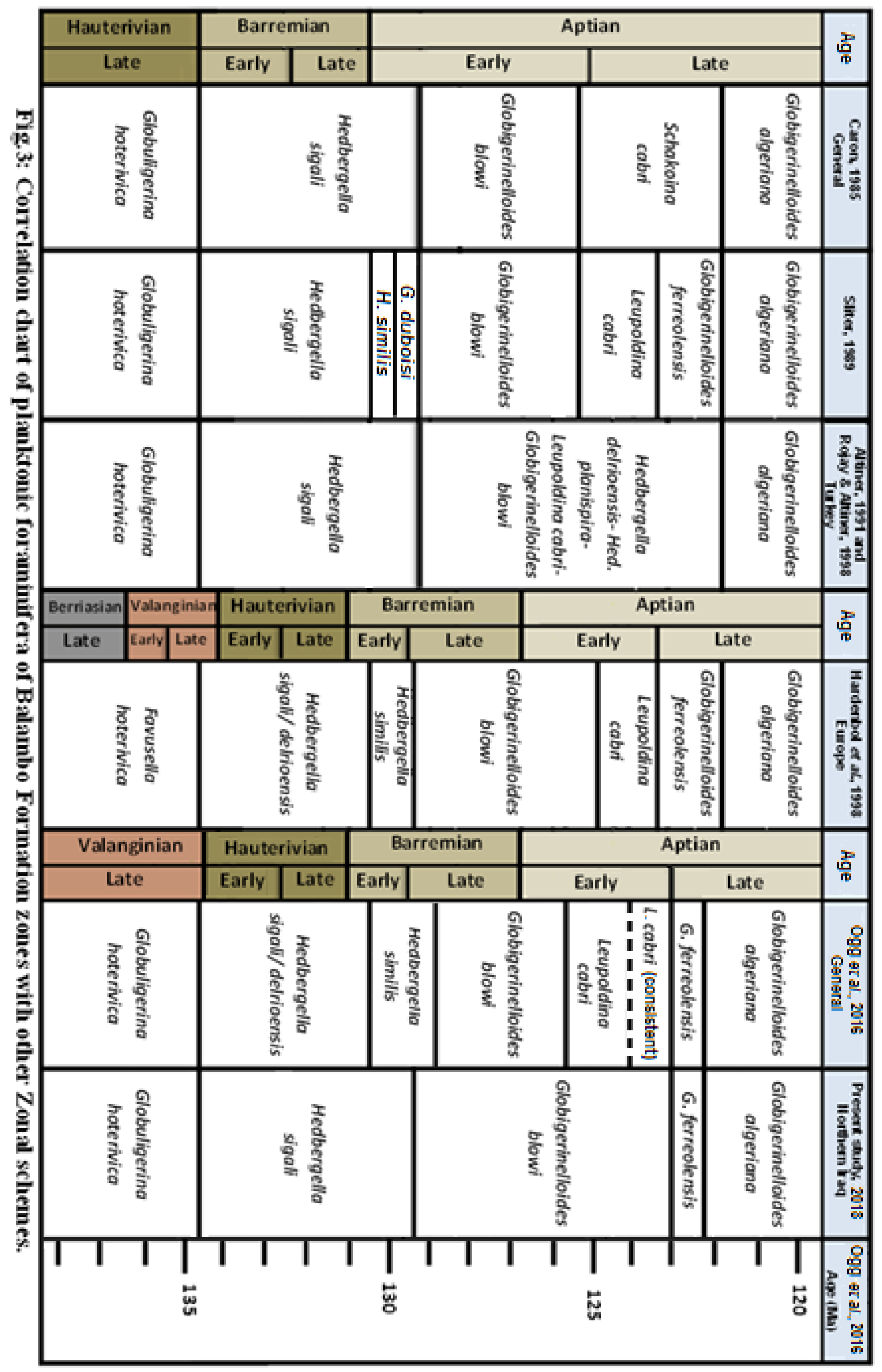




\section{2- Hedbergella sigali Interval Zone.}

Definition: The present zone was first defined by Moullade (1966) from the Barremian to Early Aptian. It represents the stratigraphic range of the index species Hedbergella sigali Moullade, from the first occurrence of Hedbergella sigali Moullade, to the first occurrence of Globigerinelloides blowi (Bolli).

Age: Latest Valanginian - Early Late Barremian.

Boundaries: The lower boundary of this zone is marked by the first appearance of index species Hedbergella sigali Moullade, while the upper boundary is indicated by the first appearance of the species Globigerinelloides blowi (Bolli).

Thickness: $50 \mathrm{~m}$ represent by samples (10 - 23).

Correlation and Age Determination: This zone is correlative to the Hedbergella sigali zone of Caron (1985), Hedbergella sigali, Hedbergella similis and Globigerinelloides duboisi zones of Sliter (1989) of Early Barremian - Early Aptian age. Also it is equivalent to the Hedbergella sigali zone of Altiner (1991) and Rojay and Altiner (1998) in same age. While it is correlative with the Hedbergella sigali/ delrioensis and Hedbergella similis zones of Hardenbol et al., (1998) and Hedbergella sigali/ delrioensis and lower part of Hedbergella similis zones of Ogg et al. (2016) in Latest Valanginian - Early late Barremian age.

\section{3- Globigerinelloides blowi Interval Zone.}

Definition: This zone was first defined by Moullade (1974) from Early Aptian, representing the interval from the first occurrence of Globigerinelloides blowi (Bolli), to the first occurrence of Globigerinelloides ferreolensis (Moullade).

Age: Early Late Barremian - latest Early Aptian .

Boundaries: The lower boundary of this zone is marked by the first appearance of Globigerinelloides blowi (Bolli), whereas the upper boundary is determined by the first appearance of the species Globigerinelloides ferreolensis (Moullade).

Thickness: $71 \mathrm{~m}$ represent by samples $(24-46)$.

Correlation and Age Determination: This zone is correlated with the Globigerinelloides blowi and lower part of Schakoina cabri zones of Caron (1985), 
Globigerinelloides blowi and Leupoldina cabri zones of Sliter (1989) and lowermiddle part of Hedbergella delrioensis- Hed. planispira- Leupoldina cabriGlobigerinelloides blowi zone of Altiner (1991), and Rojay and Altiner (1998) of Early - Late Aptian age. On the other hand, its equivalent to the Globigerinelloides blowi and Leupoldina cabri zones of Hardenbol et al. (1998) and Upper part of Hedbergella similis, in addition to Globigerinelloides blowi and Leupoldina cabri zones of Ogg et al. (2016) in Early Late Barremian - Early Aptian age.

\section{4- Globigerinelloides ferreolensis Interval Zone.}

Definition: The present zone is representing the Interval zone of Globigerinelloides ferreolensis (Moullade). Which precedes the appearance of Globigerinelloides algeriana Cushman and Ten Dam.

Age: Late Aptian.

Boundaries: The lower boundary of this zone is marked by the first appearance of Globigerinelloides ferreolensis (Moullade), whereas the upper boundary is determined by last appearance of Globigerinelloides ferreolensis (Moullade), which coincides with first appearance of Globigerinelloides algeriana Cushman and Ten Dam.

Thickness: $19 \mathrm{~m}$ represented by samples (47-54).

Correlation and Age Determination: The current zone is equivalent to the upper part of Schakoina cabri zone of Caron (1985), Globigerinelloides ferreolensis zone of Sliter (1989) and upper part of Hedbergella delrioensis-Hed. planispiraLeupoldina cabri-Globigerinelloides blowi zone of Altiner (1991) and Rojay and Altiner (1998) of Late Aptian age. Furthermore, it is also correlative to the Globigerinelloides ferreolensis zone of Hardenbol et al. (1998) and Ogg et al. (2016) in Late Aptian age.

\section{5- Globigerinelloides algeriana Taxon range Zone. (part).}

Definition: The present zone is representing the total range of Globigerinelloides algeriana Cushman and Ten Dam.

Age: Late Aptian. 
Boundaries: The lower boundary of this zone is marked by the first appearance of Globigerinelloides algeriana Cushman and Ten Dam, whereas the upper boundary is determined by the last occurrence of the nominate taxon. The upper boundary of this zone is not included in the current study.

Thickness: $9 \mathrm{~m}$ represented by samples (55-58).

Correlation and Age Determination: The present zone is equivalent to the Globigerinelloides algeriana zone of Caron (1985), Sliter (1989), Altiner (1991), Rojay and Altiner (1998), Hardenbol et al. (1998) and Ogg et al., (2016) of Late Aptian age.

\section{CONCLUSION}

The investigation of the cosmopolitan planktonic foraminiferal fauna of the Balambo Formation in Barsarin Village, northeastern Iraq yielded ten species belonging to three genera. According to their stratigraphic range, the formation subdivided into five biozones, these are from older at the base:

5. Globigerinelloides algeriana Taxon range Zone. (part).

4. Globigerinelloides ferreolensis Interval Zone.

3. Globigerinelloides blowi Interval Zone.

2. Hedbergella sigali Interval Zone.

1. Globuligerina hoterivica Interval Zone.

The distribution of the faunal sequence and the correlation between these biozones and other zonal schemes reveal a Late Valanginian to Late Aptian age for the Balambo Formation in Barsarin Village. 


\section{REFERENCES}

Altiner, D., 1991. Microfossil Biostratigraphy (Mainly foraminifers) of the Jurassic-Lower Cretaceous carbonate successions in North-Western Anatolia (Turkey). Geologica Romana, Vol. 27, pp. 167 - 213.

Bellen, R.C., Dunnington, H.V., Wetzel, R., and Morton, D.M., 1959: Laxique statigraphique international Asia, Fascicule, 10a, Iraq, Paris, 333 p.

Caron, M., 1985. Cretaceous planktic foraminifera. In: Bolli, H. M., Saunders, J. R. and Perch-Nielsen, K. (eds.): Plankton stratigraphy. Cambridge Univ. Press, pp. 17 - 86.

Hardenbol, J., Thierry, J., Farley, M. B., Jacquin, T., de Graciansky, P. C., Vail, P. R., 1998. Mesozoic and Cenozoic sequence chronostratigraphic framework of European basins. SEPM Special Publication, Vol. 60, pp. 3 13.

Jassim, S.Z. and Buday, T., 2006. Tectonic framework, In: Jassim, S.Z. and Goff, J.C. (eds.), Geology of Iraq. Published by Dolin, Prague and Moravian Museum, Brno, pp. 45-55.

Moullade, M.,1966. Etude stratigraphique et micropaléontologique du Crétacé inférieur de la "fosse vocontienne". Documents des Laboratoires de Géologie de la Faculté des Sciences de Lyon, Vol. 15, pp. 1 - 369.

Moullade, M., 1974. Zones de Foraminifers do Crétacé inférieur mésogéen. C. r. Seances Acad. Sci. Paris, ser. D, 278, No. 18, pp. 13 - 16.

Ogg, J. G., Ogg, G. M. and Gradstein, F. M., 2016. A concise geologic time scale. Amsterdam, Netherland, Elsevier, 234 p.

Rojay, B., and Altiner, D., 1998. Middle Jurassic-Lower Cretaceous Biostratigraphy in the central Pontides (Turkey): Remarks on Paleogeography and Tectonic Evolution. Rivista Italiana di Paleontologia e Stratigrafia, Vol. 104, pp. 167-180.

Sliter, W. V., 1989. Biostratigraphic zonation for the Cretaceous planktonic foraminifers examined in thin section. Jour. Foram. Res., Vol. 19, No. 1, pp. 1 - 19.

Sissakian, V. K., Mahdi, A. I., Amin, R. M. and Mohammed, B. S., 1997. The Nfayil Formation. A new lithostratigraphic unit in Iraq. Iraqi Geol. Jour., Vol.30, No.1.

Van Hinte, J. E., 1972. The Cretaceous time scale and planktonic foraminifera zones. Proc. Koninkl. Nederl. Akad. Van Wetenschappen. Ser. B, 75, No. 1, pp. 1 - 8. 


\section{PLATE 1}

A: Globuligerina hoterivica (Subbotina), equatorial section, sample number 1.

B: Hedbergella sigali Moullade, equatorial section, sample number 23.

C: Hedbergella acculta Longoria, axial section, sample number 44.

D: Hedbergella bizonae (Chevalier), equatorial section, sample number 24.

E: Hedbergella delrioensis (Carsey), equatorial section, sample number 55.

F: Hedbergella planispira (Tappan), equatorial section, sample number 53.

G: Globigerinelloides algeriana Cushman and Ten Dam, axial section, sample number 55 .

H: Globigerinelloides algeriana Cushman and Ten Dam, equatorial section, sample number 58.

I: Globigerinelloides ferreolensis (Moullade), axial section, sample number 53.

J: Globigerinelloides ferreolensis (Moullade), equatorial section, sample number 47.

K: Globigerinelloides blowi (Bolli), equatorial section, sample number 24.

L: Hedbergella trocoidea (Gandolfi), equatorial section, sample number 55.

M: Textulariid Benthonic foraminifera, sample number 43.

N: Radiolarian skeleton, sample number 20. 


\section{PLATE 1}
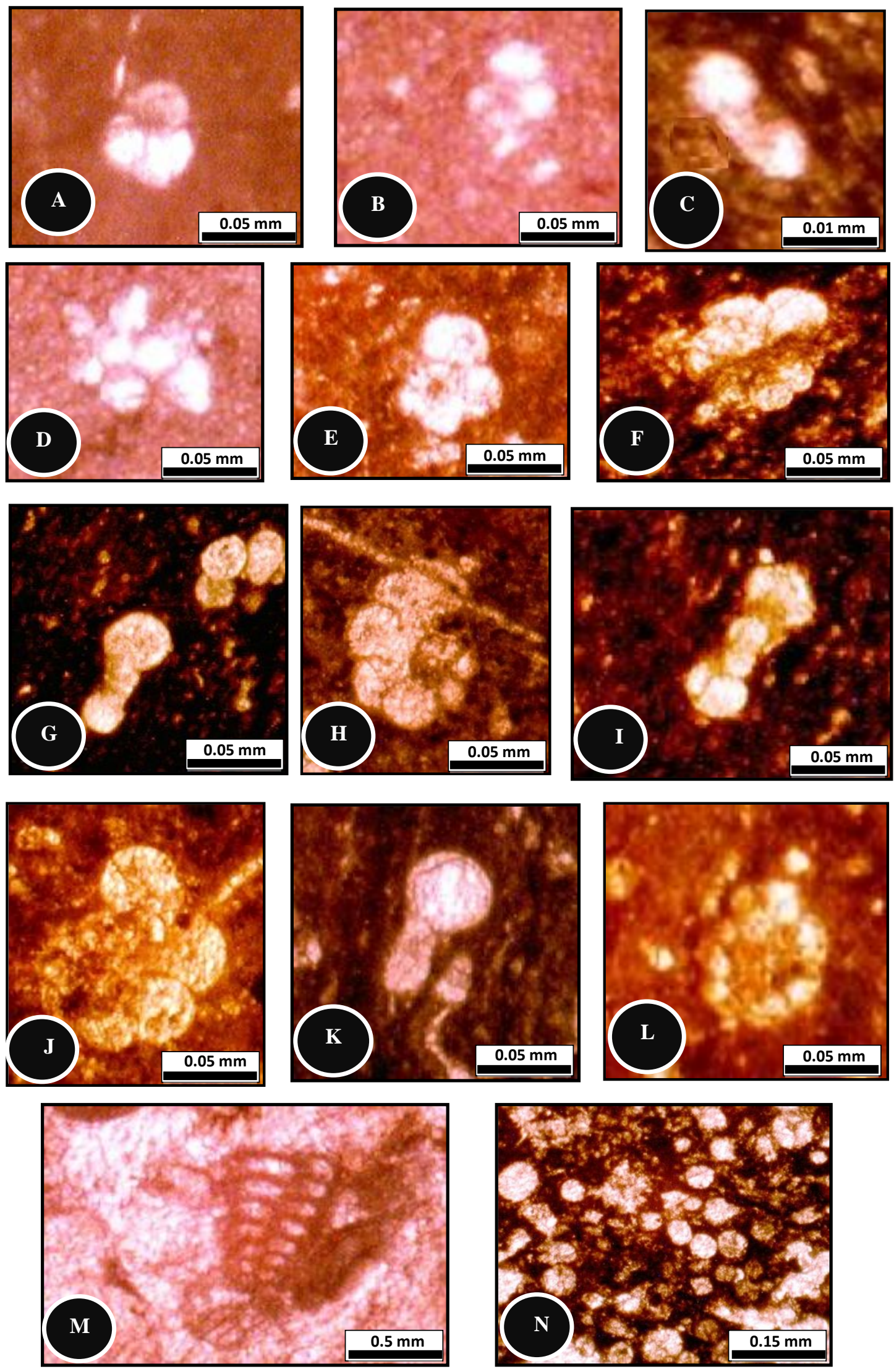